\title{
Assessment of KAP, Risk Factors and Associated Co-Morbidities in Hypertensive Patients.
}

\author{
Hemant Mahajan ${ }^{1}$, Yasmeen $\mathrm{Kazi}^{2}$, Bhuwan Sharma ${ }^{3}$, GD Velhal ${ }^{4}$ \\ ${ }^{1}$ Assistant Professor, RCSM GMC Kolhapur, MUHS Nashik, India \\ $\left({ }^{2}\right.$ Assistant Professor, ${ }^{3}$ Junior Resident, ${ }^{4}$ additional Professor $)$ TN Medical College, Mumbai, MUHS Nashik, \\ India
}

\begin{abstract}
Objective: (1) To assess the knowledge, attitude and practices of hypertensive patients. (2) To assess the risk factors and associated co-morbidities in them. Material and Methods: A cross-sectional study was conducted at Shivaji Nagar urban slum which is a field practice area of Department of Preventive and Social Medicine, of TN Medical College Mumbai. Hypertensive patients above 40 years of age were included in this study. The information was gathered by personal interview using semi-structured proforma. Results: Out of 340 subjects $176(51.76 \%)$ were males. Majority of subjects $43.82 \%$ belonged to joint family and $64.11 \%$ subjects were from III, IV, V socioeconomic class. 39.7\% patients were unemployed and unskilled. 131 (38.52\%) patients had the family history of Hypertension. majority of the patients 117 (34.41\%) had Smokeless tobacco addiction, followed by Cigarettes smoking 45 (13.23\%). Alcohol consumption and smokeless tobacco chewing both in 43 (12.64\%) patients. 90 (26.47\%) patients had Diabetes Mellitus along with Hypertension followed by Anaemia 68 (20\%) and Osteoarthritis / Osteoporosis 51 (15\%). 221 (65\%) hypertensive patients had BMI equal to or more than $25 \mathrm{Kg} / \mathrm{m}^{2}$. Poor knowledge, attitude and practices were in $83.42 \%, 69.11 \%$, $73.24 \%$ patients respectively. Mean systolic BP, Diastolic BP, Body mass index and weight was $145.58 \mathrm{~mm}$ of $\mathrm{Hg}, 92 \mathrm{~mm}$ of $\mathrm{Hg}, 25.09 \mathrm{Kg} / \mathrm{m}^{2}$ and $67.8 \mathrm{Kg}$ respectively. Conclusion: Most of the patients had associated comorbidities. Poor practices regarding hypertension is the main reason for higher Blood pressure, Body mass Index. Poor practices were because of lack of awareness about hypertension. There is need for encouraging health services including health education regarding risk factors.
\end{abstract}

Keywords: Co-morbidities, Hypertension, KAP, Risk factors, Urban slum

\section{Introduction}

Cardiovascular diseases have been proved to be the leading cause of morbidity and mortality in developed countries, and are gradually emerging as an important health problem in developing countries as well. Hypertension (HTN) is one of the most common cardiovascular diseases with a prevalence ranging from 10 to $20 \%$ among adult population. ${ }^{(\mathbf{1})}$ Subjects with hypertension possess two fold higher risk of developing coronary artery disease (CAD), four times higher risk of congestive heart failure and seven times higher risk of cerebrovascular diseases (CVD), compared to normotensive subjects. ${ }^{(2,3)}$ The 'Global Burden of Disease study' has projected CAD and CVD as the leading cause of death worldwide by the year 2020. ${ }^{(4)}$ Hypertension, an iceberg disease could be described as the 'sleeping snake'- which bites when it wakes up. We therefore conducted a descriptive epidemiological study to assess knowledge, attitude, practices, risk factors and associated co-morbidities in hypertensive patients in an urban slum of Mumbai.

\section{MATERIALS AND METHODS}

The study was conducted at Shivaji Nagar urban slum which is a field practice area of Department of Preventive and Social Medicine, of parent Medical College. This is situated at an eastern suburb of Mumbai which comes under the jurisdiction of M East Ward of Municipal Corporation of Greater Mumbai. The population of Shivaji Nagar consists of people who have migrated from different parts of India, mainly from Uttar Pradesh, Bihar, West Bengal, Madhya Pradesh, Andhra Pradesh and Tamil Nadu. They have migrated to Mumbai in search of job. Total Population of Study Area = 1, 22,000.

Population $>40$ years $=24400$ (Applying national demographic parameters).

Prevalence of Hypertension $>40$ years in an urban slum of Mumbai $=13.9 \%{ }^{(5)}$.

Expected number of hypertensive patients in study population $=3391.6$

Taking $10 \%$ of expected patients $=339.16$ Sample size $(n)=/>340$. So, total 340 known hypertensive patients were involved.

By taking, inclusion and exclusion criteria into consideration, total 340 known cases of Hypertensive patients were selected by employing simple random sampling method. Semi structured interview schedule was constructed relevant to the study. This interview schedule was tested by pilot study on 25 hypertensive patients attending geriatric clinic in Urban Health Center. Appropriate changes were done based on pilot study and the 
Assessment of KAP, risk factors and associated co-morbidities in hypertensive patients.

interview schedule was finalized. Voluntary consent form was prepared in English, Hindi and Marathi. Home visits were done between 10.00 am to $4.00 \mathrm{pm}$ on working days. The information was collected about various socioeconomic factors, illness perceptions, family history, addiction, duration of disease, exercise, complications, associated disorders, life style, self care etc. on preformed, pre tested interview schedule by investigator himself. Height, Weight and Blood pressure were measured by using appropriate technique. Appropriate scoring was done for assessment of knowledge, attitude and practice in both pre intervention and post intervention phases. The Life style and self care improvement was also done at the end of intervention and compared with pre intervention phase. The collected data was numerically coded and entered in Microsoft Excel 2007 and then transferred to SPSS version 15.0 Added data was analyzed with appropriate test like Chi-square test, ' $t$ ' test to see the association between various parameter, with $p$ value 0.05 considered as significant.

\subsection{ASSESSMENT OF KNOWLEDGE, ATTITUDE AND PRACTICE OF THE PATIENT}

\subsubsection{Knowledge about hypertension:}

Following questions were asked-

1) Do you know what hypertension is? Yes/No ;

If patient able to say; elevated blood pressure - Mark 1

If, Not - Mark 0

2) Do you think more and more people are suffering from Hypertension?

If Yes - Mark 1, If no - Mark 0.

3) Do you know what normal blood pressure level is?

If yes - Mark 1 ; If No - Mark 0.

4) Do you know, what are the symptoms of Hypertension?

If patient is able to enumerate symptoms of hypertension -Mark 1

If not - mark 0 .

5) Do you know, what are the complications of Hypertension?

If patient is able to enumerate complications of hypertension -Mark 1

If Not - Mark 0.

6) Do you think that Diet control (salt restriction) and exercise acts as central pillar in management of Hypertension?

If yes - Mark 1 ; If No- Mark 0.

- Minimum marks were ' 0 ' and

- Maximum marks were ' 6 '.

- Poor scorer: the patient who scored marks up to 3,

- Good scorer: the patients who scored marks more than 3.

Following Question Were Asked-

\subsubsection{Attitude towards hypertension:}

1.) Do you think, it's good to include green leafy vegetable in your daily diet?

2.) Do you think that it's good to avoid extra added salts in your diet?

3.) Do you think, it's good to avoid extra Cooking oil in your diet?

4.) Do you think, it's good to have whole fruits rather than to have deserts and sweets?

5.) Do you think, that excess alcohol can worsens the blood pressure level?

6.) Do you think, Regular physical exercise is essential to control raised blood pressure?

If patient has positive response then they have been allotted 1 mark and if they give negative response then they will have 0 marks

- Minimum marks were ' 0 ' and

- Maximum marks were ' 6 '.

- Poor Scorer-Score up to 3;

- Good Scorer-Score more than 3;

Following question were asked-

\subsubsection{Practice towards hypertension:}

1) Are you taking regular prescribed medicine and going for regular follow-up?

If, Yes-Mark 1 ; No- Mark - 0

2) Are you taking Healthy Diet?

Yes- Mark 1; No- Mark 0

3) Are you doing physical exercise to maintain your weight?

If, Yes- Mark 1; No- Mark -0

4) Are you avoiding, extra added salt in your daily diet?

Yes- Mark 1; No-Mark -0 
Assessment of KAP, risk factors and associated co-morbidities in hypertensive patients.

5) When is your last Eye examination done?

a. Within last year - Marks 4

b. Within last two years - Marks 3

c. Within last three years - Marks 2

d. Within last 4 year or more or not checked since the diagnosis - Mark 1

6) What is the frequency of checking blood sugar level?

a. Once in 15 days - Marks 4

b. Once in 1 months - Marks 3

c. Once in 3 months - Marks 2

d. Once in 6 months or more - Mark 1

- Minimum marks were ' 2 '

- Maximum marks were will be ' 12 '

- Poor scorer-the patients who scored mark up to 7

- Good scorer- the patients who scored mark 8 to 12

\section{RESULTS}

Total 340 hypertensive subjects were examined consisting of $176(51.76 \%)$ males and 164(48.23\%) females. Majority of patients $158(46.46 \%)$ were in the age group of 51-60 years. $218(64.11 \%)$ subjects were from Socio-economic class III, IV, V (according to Modified Prasad classification). Most of the patients135 (39.7\%) were either unemployed or unskilled.152 (44.7\%) were illiterate or just completed primary education.

TABLE 1 shows, family history of hypertension (f/h/o HT) were present in $38.52 \%$ patients. Smokeless tobacco consumption was most common addiction found in $34.41 \%$ patients. 250 (73.53\%) patients had some kind of addiction. Most of the patients had some kind of associated co-morbidity. Diabetes Mellitus was the most common co-morbidity found in 90 (26.47\%). Table 2 shows significant difference between the blood pressure of patients having addiction and those not having any addiction.

TABLE 1: Risk factors present in the population under study

\begin{tabular}{|l|l|}
\hline Total subjects & $340(100 \%)$ \\
\hline Males & $176(51.76 \%)$ \\
\hline Females & $164(48.23 \%)$ \\
\hline Addiction & $250(73.53 \%)$ \\
\hline 1. Smokeless tobacco & $117(34.41 \%)$ \\
\hline 2. Alcohol & $45(13.23 \%)$ \\
\hline 3. Cigarettes & $45(13.23 \%)$ \\
\hline 4. Alcohol \& smokeless tobacco & $43(12.64 \%)$ \\
\hline Family History & $131(38.52 \%)$ \\
\hline BMI $\geq \mathbf{2 5 ~ k g / m 2}$ & $221(65 \%)$ \\
\hline Known Diabetic & $90(26.47 \%)$ \\
\hline Associated co-morbidity & $131(38.53 \%)$ \\
\hline 1. Diabetes Mellitus & $90(26.47 \%)$ \\
\hline 2. Renal Pathology & $3(0.88 \%)$ \\
\hline 3. Visual defect & $27(7.94 \%)$ \\
\hline 4. Ischemic Heart Disease & $27(7.94 \%)$ \\
\hline 5. Anaemia & $68(20 \%)$ \\
\hline 6.Osteoarthritis/osteoporosis & $51(15 \%)$ \\
\hline
\end{tabular}

TABLE 2: Association between various risk factors and blood pressure

\begin{tabular}{|c|c|c|c|c|c|c|c|}
\hline \multicolumn{2}{|c|}{ Addiction } & $\mathrm{N}$ & Mean & Std. & Unpaired & p-value & Association \\
\hline \multirow{2}{*}{ SBP } & Yes & 250 & 146.95 & 8.99 & \multirow{2}{*}{3.86} & \multirow{2}{*}{0.01} & \multirow{2}{*}{$\begin{array}{l}\text { Significant } \\
\text { difference }\end{array}$} \\
\hline & No & 90 & 141.78 & 14.96 & & & \\
\hline \multirow{2}{*}{ DBP } & Yes & 250 & 92.88 & 5.99 & \multirow[t]{2}{*}{3.37} & \multirow[t]{2}{*}{0.01} & \multirow{2}{*}{$\begin{array}{l}\text { Significant } \\
\text { difference. }\end{array}$} \\
\hline & No & 90 & 89.56 & 11.96 & & & \\
\hline
\end{tabular}


Assessment of KAP, risk factors and associated co-morbidities in hypertensive patients.

\begin{tabular}{|c|c|c|c|c|c|c|c|}
\hline \multicolumn{2}{|c|}{ f/h/o HT } & $\mathrm{N}$ & Mean & SD & $\begin{array}{l}\text { Unpaired } \\
\text { ' } t \text { '- test }\end{array}$ & $\mathrm{p}$ - value & Association \\
\hline \multirow{2}{*}{ SBP } & Yes & 131 & 145.44 & 14.99 & \multirow[t]{2}{*}{0.14} & \multirow[t]{2}{*}{0.8} & \multirow{2}{*}{$\begin{array}{l}\text { Non-Significant } \\
\text { difference. }\end{array}$} \\
\hline & No & 209 & 145.67 & 14.98 & & & \\
\hline \multirow{2}{*}{ DBP } & Yes & 131 & 91.88 & 11.95 & \multirow[t]{2}{*}{0.15} & \multirow[t]{2}{*}{0.8} & \multirow{2}{*}{$\begin{array}{l}\text { Non-Significan } \\
\text { difference }\end{array}$} \\
\hline & No & 209 & 92.07 & 11.98 & & & \\
\hline \multicolumn{2}{|c|}{$\begin{array}{l}\text { Associated } \\
\text { co-morbidity }\end{array}$} & $\mathrm{N}$ & Mean & SD & $\begin{array}{l}\text { Unpaired } \\
\text { ' } t \text { '- test }\end{array}$ & $\mathrm{p}$ - value & Association \\
\hline \multirow{2}{*}{ SBP } & Yes & 131 & 145.54 & 14.95 & \multirow[t]{2}{*}{0.04} & \multirow[t]{2}{*}{0.9} & \multirow{2}{*}{$\begin{array}{l}\text { Non-Significant } \\
\text { difference }\end{array}$} \\
\hline & No & 209 & 145.6 & 8.98 & & & \\
\hline \multirow{2}{*}{ DBP } & Yes & 131 & 91.88 & 11.9 & \multirow[t]{2}{*}{0.02} & \multirow[t]{2}{*}{0.9} & \multirow{2}{*}{$\begin{array}{l}\text { Non-Significan } \\
\text { difference }\end{array}$} \\
\hline & No & 209 & 92.07 & 5.98 & & & \\
\hline
\end{tabular}

Table 4 shows patients having low education; lower socioeconomic status and unskilled type of work had higher level of systolic blood pressure (SBP) and Diastolic blood pressure (DBP).

TABLE 3: Distribution of patients' a/c to socioeconomic status, education \& type of work

\begin{tabular}{|l|l|}
\hline Socioeconomic class & $\mathbf{N}$ \\
\hline 1. Class I & $40(11.76 \%)$ \\
\hline 2. Class II & $82(24.11 \%)$ \\
\hline 3. Class III & $105(30.88 \%)$ \\
\hline 4. Class IV & $99(29.11 \%)$ \\
\hline 5. Class V & $14(4.11 \%)$ \\
\hline Education & $\mathbf{N}$ \\
\hline 1. Illiterate & $69(20.29 \%)$ \\
\hline 2. Primary Education (Pr. Edu) & $83(24.41 \%)$ \\
\hline 3. Secondary Education (Sec. Edu) & $75(22.05 \%)$ \\
\hline 4. Graduation & $113(33.23 \%)$ \\
\hline Type of Work & $\mathbf{N}$ \\
\hline 1. Unemployed & $44(12.94 \%)$ \\
\hline 2. Unskilled & $91(26.76 \%)$ \\
\hline 3. Semiskilled & $93(27.35 \%)$ \\
\hline 4. Skilled & $76(22.35 \%)$ \\
\hline 5. Semi-professional & $27(7.94 \%)$ \\
\hline 6. Professional & $9(2.64 \%)$ \\
\hline
\end{tabular}

TABLE: 4 Education, socio-economic class \& type of work Vs blood pressure

\begin{tabular}{|c|c|c|c|c|c|c|c|}
\hline & Education & $\mathrm{N}$ & Mean & $\begin{array}{l}\text { Std. } \\
\text { Devi. }\end{array}$ & $\begin{array}{l}\text { Unpaired } \\
\text { t- test }\end{array}$ & p- value & Association \\
\hline & $\begin{array}{l}\text { Graduate \& } \\
\text { Sec. Edu }\end{array}$ & 188 & 141.98 & 8.98 & & $<0.01$ & Significant diff. \\
\hline SBP & $\begin{array}{l}\text { Illiterate \& } \\
\text { Primary Edu }\end{array}$ & 152 & 150.04 .78 & 8.96 & 8.23 & & \\
\hline & $\begin{array}{l}\text { Graduate \& } \\
\text { Sec. Edu }\end{array}$ & 188 & 89.58 & 5.98 & 832 & $<0.01$ & Significant diff. \\
\hline DBP & $\begin{array}{l}\text { Illiterate \& } \\
\text { Primary Edu }\end{array}$ & 152 & 94.98 & 5.9 & 8.32 & & \\
\hline $\begin{array}{r}\text { So } \\
\text { Class } \\
\end{array}$ & Economic & $\mathrm{N}$ & Mean & SD & $\begin{array}{l}\text { Unpaired } \\
\text { t- test }\end{array}$ & $\mathrm{p}$ - value & Association \\
\hline SBP & $\begin{array}{l}\text { Upper Class } \\
\text { (ClassI,II,III) }\end{array}$ & 227 & 143.11 & 8.98 & 7.26 & $<0.01$ & Significant diff. \\
\hline
\end{tabular}


Assessment of KAP, risk factors and associated co-morbidities in hypertensive patients.

\begin{tabular}{|c|c|c|c|c|c|c|c|}
\hline & $\begin{array}{l}\text { Lower class } \\
\text { (Class IV, V) }\end{array}$ & 113 & 150.54 & 8.68 & & & \\
\hline \multirow[b]{2}{*}{ DBP } & $\begin{array}{l}\begin{array}{l}\text { Upper Class } \\
\text { (ClassI,II,III) }\end{array} \\
\end{array}$ & 227 & 90.55 & 5.98 & \multirow[t]{2}{*}{6.43} & \multirow[t]{2}{*}{$<0.01$} & \multirow[t]{2}{*}{ Significant diff } \\
\hline & $\begin{array}{l}\text { Lower class } \\
\text { (Class IV, V) }\end{array}$ & 113 & 94.9 & 5.66 & & & \\
\hline \multicolumn{2}{|r|}{ Type of } & $\mathrm{N}$ & Mean & $\mathrm{SD}$ & $\begin{array}{l}\text { Unpaired } \\
\text { t- test }\end{array}$ & p-value & Association \\
\hline \multirow[b]{2}{*}{ SBP } & $\begin{array}{l}\text { Unemployed, } \\
\text { Unskilled, } \\
\text { Semiskilled }\end{array}$ & 228 & 148.5 & 8.97 & \multirow[t]{2}{*}{8.72} & \multirow[t]{2}{*}{$<0.01$} & \multirow[t]{2}{*}{ Significant diff } \\
\hline & $\begin{array}{l}\text { Skilled, } \\
\text { Professional }\end{array}$ & 112 & 139.62 & 8.51 & & & \\
\hline \multirow[b]{2}{*}{ DBP } & $\begin{array}{l}\text { Unemployed, } \\
\text { Unskilled, } \\
\text { Semiskilled }\end{array}$ & 228 & 93.91 & 5.95 & \multirow[t]{2}{*}{8.5} & \multirow[t]{2}{*}{$<0.01$} & \multirow[t]{2}{*}{ Significant diff } \\
\hline & $\begin{array}{l}\text { Skilled, } \\
\text { Professional }\end{array}$ & 112 & 88.11 & 5.8 & & & \\
\hline
\end{tabular}

TABLE 5 shows, only $16.58 \%, 30.89 \%, 26.76 \%$ study population had good knowledge, attitude and practices towards hypertension respectively. Female had poor knowledge, attitude and practices than males.

TABLE 5: Knowledge attitude and practices of hypertensive patients

\begin{tabular}{|c|c|c|c|c|}
\hline \multicolumn{2}{|c|}{ KAP of patients } & Male & Female & Total \\
\hline \multirow{2}{*}{ Knowledge } & Good & $\begin{array}{l}41 \\
(12.05 \%)\end{array}$ & $12(3.53 \%)$ & $53(16.58 \%)$ \\
\hline & Poor & $\begin{array}{l}135 \\
(39.71 \%)\end{array}$ & $\begin{array}{l}152 \\
(44.71 \%)\end{array}$ & $\begin{array}{l}287 \\
(83.42 \%) \\
\end{array}$ \\
\hline \multirow{2}{*}{ Attitude } & Good & $\begin{array}{l}79 \\
(23.24 \%)\end{array}$ & $26(7.65 \%)$ & $\begin{array}{l}105 \\
(30.89 \%)\end{array}$ \\
\hline & Poor & $\begin{array}{l}97 \\
(28.53 \%)\end{array}$ & $\begin{array}{l}138 \\
(40.58 \%) \\
\end{array}$ & $\begin{array}{l}235 \\
(69.11 \%) \\
\end{array}$ \\
\hline \multirow{2}{*}{ Practice } & Good & $\begin{array}{l}60 \\
(17.64 \%)\end{array}$ & $31(9.12 \%)$ & $91(26.76 \%)$ \\
\hline & Poor & $\begin{array}{l}116 \\
(34.12 \%)\end{array}$ & $\begin{array}{l}133 \\
(39.12 \%) \\
\end{array}$ & $\begin{array}{l}249 \\
(73.24 \%)\end{array}$ \\
\hline
\end{tabular}

TABLE 6 shows; dizziness was the most common symptoms while a heart problem was most common complication known to patients. Most of the patients not doing blood pressure measurement and eye check-up regularly. BP measurement in hypertensive patients should be ideally at 15 days interval or at monthly interval. Hypertensive patients should examine their eyes either at yearly or two yearly intervals.

TABLE 6: Awareness of patients

\begin{tabular}{|l|l|}
\hline \multicolumn{2}{|l|}{ Awareness of Hypertension symptoms among patients } \\
\hline Dizziness & $172(50.58 \%)$ \\
\hline Palpitation & $57(16.76 \%)$ \\
\hline Tiredness & $42(12.35 \%)$ \\
\hline Headache & $106(31.17 \%)$ \\
\hline Awareness of Hypertension symptoms among patients \\
\hline Stroke & $25(7.35 \%)$ \\
\hline Renal & $10(2.94 \%)$ \\
\hline Visual & $12(3.52 \%)$ \\
\hline Heart problems & $27(7.94 \%)$ \\
\hline
\end{tabular}


Assessment of KAP, risk factors and associated co-morbidities in hypertensive patients.

\begin{tabular}{|l|l|}
\hline \multicolumn{2}{|l|}{ Frequency of Blood Pressure Measurement } \\
\hline 15 days & $17(5 \%)$ \\
\hline 1 month & $137(40.29 \%)$ \\
\hline 3 month & $97(28.52 \%)$ \\
\hline 4 month & $89(26.17 \%)$ \\
\hline Frequency of eye examination \\
\hline 1 year interval & $48(14.12 \%)$ \\
\hline 2 year interval & $68(20 \%)$ \\
\hline 3 year interval & $46(13.53 \%)$ \\
\hline 4 year or more interval & $178(52.35 \%)$ \\
\hline
\end{tabular}

TABLE 7 shows, mean age of the study population was 51.9 years with standard deviation of 6.9 Mean diagnosis duration was 3.89 years with standard deviation of 2.13. Mean SBP, DBP, Weight and BMI of Study population were $145.58 \mathrm{~mm}$ of $\mathrm{Hg}, 92 \mathrm{~mm}$ of $\mathrm{Hg}, 67.8 \mathrm{Kg}$ and $25.09 \mathrm{~kg} / \mathrm{m}^{2}$ with S.D. of 8.97, 5.98, 4.98 and 1.34 respectively.

TABLE 8 shows, patients having BMI 25 or above and poor practice score had poor control over systolic and diastolic BP.

TABLE 7: Descriptive statistics

\begin{tabular}{|l|c|c|c|c|}
\hline \multicolumn{1}{|c|}{ Parameters } & Mean & SD & Minimum & Maximum \\
\hline Age in (yrs) & 51.9 & 6.9 & 41 & 70 \\
\hline Hypertension duration in (yrs) & 3.89 & 2.13 & 1 & 10 \\
\hline Systolic BP (in mm Hg) & 145.58 & 8.97 & 120 & 170 \\
\hline Diastolic BP (in mm Hg) & 92 & 5.98 & 76 & 106 \\
\hline Weight in Kg & 67.8 & 4.98 & 55 & 82 \\
\hline Body Mass Index in Kg/m ${ }^{2}$ (BMI) & 25.09 & 1.34 & 20.82 & 28.76 \\
\hline
\end{tabular}

TABLE 8: Association of BMI and score of practices Vs Blood pressure

\begin{tabular}{|c|c|c|c|c|c|}
\hline \multirow{2}{*}{$\begin{array}{l}\mathrm{BMI} \text { in } \\
\mathrm{kg} / \mathrm{m}^{2}\end{array}$} & \multicolumn{3}{|c|}{ Systolic Blood Pressure in mm Hg (SBP) } & \multirow{2}{*}{$\begin{array}{l}\text { Pearson Chi- } \\
\text { square Value }\end{array}$} & \multirow{2}{*}{$\mathrm{p}$-value } \\
\hline & $<140$ & $140-159$ & $\geq 160$ & & \\
\hline$<25$ & $33(9.72 \%)$ & $79(23.23 \%)$ & $7(2.05 \%)$ & \multirow[b]{2}{*}{5.4 with df- 2} & \multirow{2}{*}{$\begin{array}{l}0.067 \text { (Non- } \\
\text { significant) }\end{array}$} \\
\hline$\geq 25$ & $39(11.47 \%)$ & $161(47.35 \%)$ & $\begin{array}{l}21 \\
(6.17 \%)\end{array}$ & & \\
\hline \multirow{2}{*}{$\begin{array}{l}\mathrm{BMI} \text { in } \\
\mathrm{kg} / \mathrm{m}^{2}\end{array}$} & \multicolumn{3}{|c|}{ Diastolic Blood Pressure in $\mathrm{mm} \mathrm{Hg}(\mathrm{DBP})$} & \multirow{2}{*}{$\begin{array}{l}\text { Pearson Chi- } \\
\text { square Value }\end{array}$} & \multirow{2}{*}{$\mathrm{p}$-value } \\
\hline & $<90$ & $90-99$ & $\geq 100$ & & \\
\hline$<25$ & $40(11.78 \%)$ & $65(19.11 \%)$ & $\begin{array}{l}14 \\
(4.11 \%)\end{array}$ & \multirow{2}{*}{6.13 with df -2} & \multirow{2}{*}{$\begin{array}{l}0.047 \\
\text { (Significant) }\end{array}$} \\
\hline$\geq 25$ & $48(14.11 \%)$ & $136(40 \%)$ & $\begin{array}{l}37 \\
(10.89 \%)\end{array}$ & & \\
\hline \multirow{2}{*}{$\begin{array}{l}\text { Score of } \\
\text { practice }\end{array}$} & \multicolumn{2}{|c|}{$\begin{array}{l}\text { Systolic Blood Pressure in mm } \\
\mathrm{Hg}\end{array}$} & & \multirow{2}{*}{$\begin{array}{l}\text { Pearson Chi- } \\
\text { square Value }\end{array}$} & \multirow[t]{2}{*}{ p-value } \\
\hline & $<140$ & \multicolumn{2}{|l|}{140 and above } & & \\
\hline Good & $43(12.64 \%)$ & \multirow{2}{*}{\multicolumn{2}{|c|}{$\begin{array}{l}48(14.11 \%) \\
220(64.7 \%)\end{array}$}} & \multirow{2}{*}{48.5 with df - 1} & \multirow{2}{*}{$\begin{array}{l}<0.01 \\
\text { (Significant) }\end{array}$} \\
\hline Poor & $29(8.52 \%)$ & & & & \\
\hline \multirow{2}{*}{$\begin{array}{l}\text { Score of } \\
\text { practice }\end{array}$} & \multicolumn{3}{|c|}{ Diastolic Blood Pressure in $\mathrm{mm} \mathrm{Hg}$} & \multirow{2}{*}{$\begin{array}{l}\text { Pearson Chi- } \\
\text { square Value }\end{array}$} & \multirow{2}{*}{ p-value } \\
\hline & $<90$ & \multicolumn{2}{|l|}{90 and above } & & \\
\hline Good & $54(15.88 \%)$ & $37(10.89 \%)$ & & \multirow{2}{*}{70.15 with df -1} & \multirow{2}{*}{$\begin{array}{l}<0.01 \\
\text { (Significant) }\end{array}$} \\
\hline Poor & $34(10 \%)$ & $215(63.23 \%)$ & & & \\
\hline
\end{tabular}

\section{DISCUSSION}

HTN is major health problem in India and other developing countries. Countries with ageing population in developed countries will be expected to have high prevalence of HTN than in a developing country with younger population such as India, but there are studies which have shown higher prevalence rate of HTN in developing countries. Age distribution of subjects showed majority (90.3\%) were from 40-60 years age 
Assessment of KAP, risk factors and associated co-morbidities in hypertensive patients.

group which by itself is one of the important risk factor for many non- communicable diseases including hypertension. Late 50's is the age of retirement, which collectively causes stress, mental tension and low physical activity resulting in gradual deviation of blood pressure from normalcy and ultimately reaching to the hypertension $(\geq 140 / 90 \mathrm{~mm} \mathrm{Hg})$.

In US, the prevalence rate varies from $4 \%$ in the age group $18-24$ years to $60 \%$ in the age group $65-74$ years. ${ }^{(6)}$ Most of the Indian studies have found increasing levels of BP with increasing age. A study done among elderly population of the desert region of Rajasthan ${ }^{(7)}$ ( $\geq 60$ years) showed a higher prevalence rate with $54.3 \%$ among urban and $32.6 \%$ among rural subjects.

In our study, according to Modified Prasad classification, 113 (33.23\%) subjects were from Socioeconomic class IV and V had higher BP than others. A study among Chinese elderly ${ }^{(\mathbf{8})}$ showed an inverse relationship with per-capita income. Similar relation was found in a study conducted in Harlem, New York City. ${ }^{(9)}$ Most of the studies in India have indicated a higher prevalence of HTN in higher socio-economic groups. A study done on HTN with special reference to socio-economic status in rural south-Indian community ${ }^{(10)}$ showed that the prevalence of HTN in highest socio-economic group (22.5\%) was more than twice that in the lowest socio-economic group (8.8\%). But a study in Mumbai ${ }^{(11)}$ found no difference between high and low socio-economic groups. Similar was the result of a National study by the Cardiology society of India. ${ }^{(12)}$

In our study $135(39.7 \%)$ patients were either unemployed or unskilled. Most of the patients 152 (44.70\%) were illiterate or just completed primary education. They had more mean BP level than others. This finding suggests that exposure to factors that were implicated in the causation of hypertension was more common in deprived areas. There had been strong influence of low income and lower educational levels on poor hypertension outcomes as evidenced by ignorance and lack of relevant knowledge or skills required to maintain quality hypertension care and control.

Bhalla and Tondon ${ }^{(13)}$ at Lucknow and Ghosh ${ }^{(14)}$ at Shimala found the prevalence of hypertension to be more among professionals, executives and traders as compared to the low occupation such as semi-skilled and unskilled persons. A study among Chinese elderly ${ }^{(8)}$ showed an inverse relationship with per-capita income. Similar relation was found in a study conducted in Harlem, New York City ${ }^{\left({ }^{(9)}\right.}$ On the contrary, Malhotra ${ }^{(\mathbf{1 5 )}}$ in a study among railway workers and Miall ${ }^{(\mathbf{1 6})}$ at Jamaica did not find any significant association between occupational status and hypertension. The Jaipur rural study ${ }^{(\mathbf{1 7 )}}$ had reported a higher prevalence amongst low education or illiterate groups.

In our study, out of 340 Hypertensive patients, 131 (38.52\%) patients had the family history of Hypertension. A family history of elevated BP is one of the strongest risk factors for future development of HTN in individuals. The BP of first-order adults relatives (parents, siblings), corrected for age and sex, have been shown to aggregate at all levels of BP, with a regression coefficient of $0.2-0.3{ }^{\left({ }^{(1)}\right)}$ Epidemiological studies suggest that 20-60\% of essential HTN is inherited and remaining is acquired or environmental.

In a National study of epidemiology of HTN under the Cardiology Society of India, ${ }^{(13)}$ the incidence of family history of HTN, Stroke and CHD was at least 1.5 times as frequent in hypertensives as in controls. History of stroke; as a cause of death in parents and close relatives was 3 to 5 times common in hypertensives than in controls.

In our study tobacco consumption in any form was found in $205(60.25 \%)$ hypertensive patients. Nicotine and carbon-monoxide, the two major products of tobacco combustion are both potent vasoconstrictors. Tobacco smoking had been reported to cause acute rise of BP, but whether prolonged smoking leads to sustained hypertension had not been well established ${ }^{\left({ }^{(13)}\right.}$. Although tolerance develops to many of the effects of nicotine and other toxins in cigarette smoke, it apparently does not develop for the pressor effect.

Many epidemiological studies from different parts of India have shown a significant correlation of smoking or tobacco use with HTN prevalence. ${ }^{(\mathbf{1 9})} \mathrm{A}$ case control study from Bangalore ${ }^{(20)}$ showed that smoking was an independent risk factor for HTN (OR 2.25, p= 0.014). In an experimental study, acute use of pan-masala (an indigenous concoction of lime, arecnut, catechu, etc.) had shown to significantly increase BP. ${ }^{(21)}$ In a study by $\mathrm{CSI}^{(22)}$ from 93 urban centers from all over India, 28\% were found to be smokers.

Large proportion 88 (25.89\%) of hypertensive patients were alcoholic. Potential mechanism for the relationship include a direct pressor effect of alcohol on the vessel wall, a sensitization of resistance vessels to pressor substances, stimulation of the sympathetic nervous system, and increased production of adrenocorticoid hormones. ${ }^{(13)}$

Study by CSI ${ }^{(13)}$ showed that amongst beer drinkers, 38\% of hypertensives and none of the controls drank $\geq 2$ bottles of beer daily. Amongst spirit drinkers, 56\% of hypertensives compared to $37 \%$ of controls drank 2-3 measures of spirits daily, and 25\% hypertensives compared to none of the controls drank more than 3 measures of spirits per day. The Chennai urban population study ${ }^{(23)}$ found no association between HTN prevalence and alcohol consumption. In a study among North- American population, ${ }^{(24)}$ it had been concluded that a consumption of $>210 \mathrm{gms}$ of ethanol/week is an independent risk factor for HTN. Excess consumption was reported to account for 5-30\% of all hypertension. ${ }^{(25)}$ 
Assessment of KAP, risk factors and associated co-morbidities in hypertensive patients.

In our study 131 (38.53\%) patients had some kind of morbidity. Majority of the patients 90 (26.47\%) had Diabetes Mellitus. A study carried out by Olusegun Adesola found 43 hypertensive patients $(n=240)$ had coexisting DM. ${ }^{(26)}$ Al-Tuwijri AA in Riyadh" found that most common co-morbidity in hypertension was diabetes mellitus, found in 98 (38.4\%), followed by dyslipidemia in 50 (19.6\%), bronchial asthma in $28(11.0 \%)$ and renal diseases in $12(4.7 \%) .{ }^{(27)}$

Patients having more BMI had poor control over Blood Pressure. In our study 65\% patients had BMI more or equal to $25 \mathrm{~kg} / \mathrm{m}^{2}$. In most of the studies, being overweight was associated with a twofold to six-fold increase in the risk of developing HTN. For every $10 \%$ increase in weight a rise of $6.5 \mathrm{~mm} \mathrm{Hg}$ in systolic pressure was observed in the Framingham study. ${ }^{(28)}$ it also suggested that $65 \%$ of the risk for HTN in women and $78 \%$ in men can be related to obesity. The Jaipur urban (both sexes) and rural studies (only males), ${ }^{(29,17)}$ the Haryana rural study ${ }^{(\mathbf{3 0})}$, the Chennai urban population study ${ }^{(23)}$ as well as the Bombay executive study ${ }^{(\mathbf{3 1 )})}$ have all shown a higher weight and BMI amongst hypertensive groups.

In this study, out of 340 patients, $287(84.41 \%), 235(69.1 \%)$ and $249(73.23 \%)$ had poor score of knowledge, attitude and practice of Hypertension respectively. The low score of knowledge, attitude and practice was mainly due to illiteracy, low socioeconomic class of the patients. Also, it was found that the knowledge, attitude and practice score was less in females when compared to males.

Williams MV in his study found that out of 402 hypertensive patients, 189 patients had inadequate knowledge $(13.2 \pm 3.1) ; 49$ patients had marginal knowledge $(15.3 \pm 2.2)$ and 155 had adequate knowledge (16.5 $\pm 2.3) .{ }^{(32)}$ Meta-analysis carried out by P. Marques-Vidal selected studies done on hypertension in India, PR China, Canada, USA, Zaire, Senegal, Thailand Taiwan, Australia and found that, in men, the frequencies of awareness, antihypertensive drug treatment and BP control among all hypertensive patients varied between $23 \%$ and $93 \%, 5 \%$ and $89 \%$ and $5 \%$ and $87 \%$ respectively. In women, the frequencies ranged between $28 \%$ and $97 \%$, $6 \%$ and $97 \%$, and $0 \%$ and $97 \%$, respectively. ${ }^{(33)}$

Study carried out by M. Dorobantu stated that general rate of awareness was $44.26 \%$, increasing with age, higher in women $(52.8 \%)$ than in men $(34.58 \%)$ with the gender difference being noticed for every age group after 45 years old. ${ }^{(34)}$

Patients having poor practice scores had poor control on SBP and DBP. The common reasons for poor practice were mainly poor compliance, lack of regular follow-up, poor diet control, lack of physical exercise etc

Study by Rajiv Bharadwaj in Rural Communities of Himachal Pradesh" found that hypertension awareness was $22 \%$. Hypertensive patients on antihypertensive medication were $47 \%$ and $42.5 \%$ of total hypertensive patients who were on antihypertensive treatment had controlled BP $(<140 / 90 \mathrm{~mm} \mathrm{Hg}){ }^{(35)} \mathrm{In}$ a study by Deepa $\mathrm{R}^{(35)}$ among Chennai urban population found that $37.3 \%$ were aware of their hypertensive status. Among them only $50 \%$ were on treatment and those on treatments only $40 \%$ had their blood pressure under control. The awareness of hypertension status in USA ${ }^{(36)}$ is reported as $70 \%$, of those $59 \%$ were on treatment and only $34 \%$ of these were reported to be under control. The reason for poor control may be due to inadequate physician-patient interaction and lack of patient compliance.

Rajani Kadri found only $5.1 \%$ (33) patients were aware of hypertension related eye diseases. ${ }^{(37)}$

\section{CONCLUSION}

Hypertensive patients in an urban slum of Mumbai had very poor awareness, attitude and practices toward hypertension. Poor practices were responsible for higher Blood pressure and Body mass Index. There is need for encouraging health services including health education targeting various risk factors and promotion of regular physical exercise. Thus, people have to be educated through mass media on hypertension and its risk factors. The health workers have to play part by educating the people and also themselves being an example in avoiding the risk factors for hypertension like consumption of fatty food, alcohol and smoking. People have to be educated on the importance of physical exercises and have to be encouraged to do them.

\section{References}

[1] WHO Expert Committee. Primary prevention of essential Hypertension. WHO. Tech Rep Ser.686. Geneva. 1983

[2] Stamler J. Blood pressure and high blood pressure: Aspects of risk. Hypertension 1991; 18 (Suppl.): 05-1, 107

[3] Flack JM, Nearton, Grimm R Jr, et al. Blood pressure and mortality among men with prior myocardial infarction: Multiple risk factor intervention trial research group. Circulation. 1995: 92; 2437-2445.

[4] Murray CJ, Lopez AD. Mortality by cause for eight regions of the world: Global burden of disease study. Lancet, 1997; 349(15): 1269-1442.

[5] RB Gaurav et al. "Biochemical profile of hypertensive individuals in an urban community", Bombay Hospital Journal 2001, Vol:55 (12); page-663-668.

[6] National high blood pressure education program working group. Arch Intern Med. 1993; 153: 186-208.

[7] Agarwal H, Bawja S, Haldiya KR, Mathur A. Prevalence of hypertension in elderly population of desert region of Rajasthan. Journal of the Indian Academy of Geriatrics. 2005; 1: 14-17.

[8] Teo GS, Indris MN Prevalence of hypertension among Chinese elderly and its relationship to behavioural and nutritional factors. Medical Journal of Malaysia 1996 Mar; 51(1): 33-40.

[9] Ana V. Diez-Roux, Mary E. Northridge, Alfredo Morabi, Mary T Bassett Steven Shea. Prevalence and social correlates of cardio vascular disease risk factors in Harlem. American Journal of Public Health. 1999 Mar; 89(3): 302-307. 
[10] Ericus C, Gilberts AM, Marinus JC, Arnold WJ, Diederick E Grobbee. Hypertension and determinants of blood pressure with special reference to socio-economic status in a rural south Indian community. Journal of Epidemiology and community health. 1994; 48: 258-261.

[11] Dalai PM. Hypertension: A report on community survey on causal hypertension in old Bombay. Sri H.N. Hospital research society. 1980.

[12] Anand MP. Epidemiology of hypertension. Current concepts in hypertension Sainani GS (Ed) ICP Mumbai 1995; p. 4-13.

[13] Bhalla KK, Tandon OP. Prevalence of coronary disease, hypertension and diabetes in Lucknow. Golden Jubilee Population of Indian Council of Medical research. 1962; 7:26-27.

[14] Ghosh BN, Bansal RD, Bhardwaj UD, Joshi SC. A blood pressure survey in Shimla. Journal of Indian Medical Association. 1983; 80: 47-52.

[15] Malhotra SL. Studies in arterial pressure in north and south India with special reference to dietary factors in its causation. Journal Association of Physicians India. 1971; 19-21.

[16] Miall WE, Kass EH, Ling J, Saurt KL. Factors influencing arterial pressure in general population in Jamaica. British Medical Journal. 1962; 2:499-506.

[17] Gupta R, Sharma AK. Prevalence of hypertension and sub-types in an Indian rural population: Clinical and electrocardiographic correlates. J Human Hypertens. 1994; 8: 823-829.

[18] Pickering G. High Blood Pressure. London, Chuchill.1968.

[19] Gupta P.C, Gupta R Hypertension prevalence and blood pressure trends among 99,589 subjects in Mumbai. Abstract. Indian Heart Journal. 1999; 51: 691

[20] Pais P, Fay M.P, Yusuf S. Increased risk of acute myocardial infarction associate with beedi and cigarette smoking in Indian: final report on tobacco risks form a case-control study. Indian heart Journal. 2001; 53: 731-735.

[21] Sharma A. K, Gupta R, Gupta H.P, Singh A. K. Hemodynamic effects of pan-masala in healthy volunteers. Journal Association Physicians India. 2000; 48: 400-401.

[22] Anand M.P, Bakhle D.S, Samyuktha A. Smoking and Hypertension: Indian scenario. Journal Associations Physicians India. 1990; 38: $283-284$.

[23] Deepa R, Shantarani CS, Pradeepa R, Mohan V. Is the rule of halves in hypertension still valid? Evidence from the Chennai urban population study. J Assoc Phys Ind 2003; 51: 153-157.

[24] Working group on primary prevention of hypertension. Report of the National High Blood Pressure Education Program working group on Primary prevention of Hypertension. Archives of Internal Medicine. 1993; 153: 186-208.

[25] Fuchs F.D, Chambless L.E, Whelton P.K, et al. Alcohol consumption and incidence of hypertension: the atherosclerosis risk in community study. Hypertension, 2001; 37: 1242-1250.

[26] Olusegun Adesola Busari, Olanrewaju. Impact of Patients' Knowledge, Attitude and Practices on Hypertension on Compliance with Antihypertensive Drugs ina Resource-poor Setting. TAF Prev Med Bull 2010; 9(2):87-92]

[27] Al-tuwijri AA, Al-Rukban MO. Hypertension control and co-morbidities in primary health care centers in Riyadh. Ann Saudi Med. 2006 Jul-Aug;26(4):266-71.

[28] Garrison R, Kannel W, Strokes J III, Casteelli W. Incidence and precursors of hypertension in young adults. The Framingham offspring study. American Journal of Preventive Medicine. 1987; 16: 235-251.

[29] Gupta R, Gupta S, Gupta P, Prakash H. Prevalence and determinants of hypertension in the urban population of Jaipur in Western India. J Hypertens 1995; 13: 1193-1200.

[30] Malhotra P, Kumari S, Kumar R et al. Prevalence and determinants of hypertension in an un-industrialized rural population of north India. J Hum Hypertens.1999; 13(7): 467-472.

[31] Anand MP. Prevalence and grades of hypertension amongst executives of Mumbai. Journal Assoc Phys Ind. 2000; 48 (12): 1200 01.

[32] Williams MV, Baker DW. Relationship of functional health literacy to patient's knowledge of their chronic disease. A study of patients with hypertension and diabetes. Arch Intern Med1998 Jan 26;158(2):166-72

[33] Meta-analysis carried out by P. Marques-Vidal and J. Tuomilehto. Hypertension awareness, treatment and control in the community: is the 'rule of halves' still valid?'Journal of human hypertension April 1997, Volume 11, Number 4, Pages 213-220.

[34] M. Dorobantu, R. O. Darabont, E. Badila, and S. Ghiorghe. Prevalence, awareness, treatment, and control of hypertension in Romania: results of the SEPHAR study. International Journal of Hypertension, vol. 2010, Article ID 970694, 6 pages,

[35] Rajiv Bharadwaj, arvind kandoria, rajeev marwah et al. Prevalence, Awareness and Control of Hypertension in Rural Communities of Himachal Pradesh. JAPI July 2010 vol 58 page: 423-425.

[36] The Seventh report of the Joint National Committee on prevalence, detection, evaluation and treatment of high blood pressure. The JNC 7 Report. JAMA. 2003; 289: 2560-72.

[37] Rajani Kadri. Awareness of diabetic and hypertensive eye disease in public. Int J Biol Med Res. (2011): id 7348 